Journal of Biotechnology and Strategic Health Research

\author{
Araştırma Makalesi / Research Article
}

http://dergipark.org.tr/tr/pub/bshr

\title{
COVID-19 Pandemisi Sırasında Canlı Donör Böbrek Nakli: Tek Merkez Deneyimi
}

\section{Living Donor Kidney Transplantation During The COVID-19 Pandemic: A Single Center Experience}

\section{(iD) $\triangle$ Necattin Fırat ${ }^{1}$, (D) Emrah Akın², (iD Hamad Dheir ${ }^{3}$, (D) Fehmi Çelebi ${ }^{1}$, (D) Enes Sarıgedik ${ }^{4}$, (iD) Merve Yiğit ${ }^{2}$, (D) Fatih Altıntoprak ${ }^{1}$}

${ }^{1}$ Sakarya Üniversitesi Tip Fakültesi-Genel Cerrahi Anabilim Dalı, Sakarya, Türkiye

${ }^{2}$ Sakarya Üniversitesi Eğitim ve Araştırma Hastanesi- Genel Cerrahi Ana Bilim Dalı, Sakarya, Türkiye

${ }^{3}$ Sakarya Üniversitesi Tip Fakültesi- Nefroloji Bilim Dalı, Sakarya, Türkiye

${ }^{4}$ Düzce Atatürk Devlet Hastanesi- Çocuk Psikiyatrisi, Düzce, Türkiye

ORCID ID: Necattin Firat https://Orcid.Org/0000-0003-0684-8187, Emrah Akın https://Orcid.Org/0000-0003-0224-3834

Hamad Dheir https://Orcid.Org/0000-0002-3569-6269, Fehmi Çelebi https://Orcid.Org/0000-0003-1157-8556

Enes Sarıgedik https://Orcid.Org/0000-0002-9294-1152, Merve Yiğit https://Orcid.Org/0000-0001-5217-9629,

Fatih Altıntoprak https://Orcid.Org/0000-0002-3939-8293

*Sorumlu Yazar / Corresponding Author: Dr. Öğr. Gör. Necattin Firat, e-posta / e-mail: necattinf@sakarya.edu.tr

Geliş Tarihi / Received : 10-03-2021 Kabul Tarihi / Accepted: 31-03-2021 Yayın Tarihi / Online Published: 30-04-2021

Fırat N., Akın E., Dheir H., et all. COVID-19 Pandemisi Sırasında Canlı Donör Böbrek Nakli: Tek Merkez Deneyimi,

J Biotechnol and Strategic Health Res. 2021;5(1):78-84

Özet

Amạ COVID-19 pandemisi nedeniyle global düzeyde pek çok merkezde böbrek nakli operasyonları ya durdurulmus yada seçilmiș hasta gruplarında yapilmak üzere kısıtlamaya gidilmiștir. Böbrek nakil süreci, cerrahisi ve postoperatif dönemde uygulanan immünosüpresyon tedavisi ile birlikte değerlendirildiğinde karmaşık ve yakın takip gerektiren bir uygulamadır. Çalıșmamızın amacı; pandemi sürecinde yaptğımız nakil operasyonlarını, hastaların operasyon öncesi hazırllk, operasyon sonrası takip süreçlerini ve uyguladığımız tedavi yaklașımlarını sunmaktır.

Yöntem Pandemi süresince nakil merkezimizde gerçekleștirilen böbrek transplantasyonu operasyonları retrospektif olarak değerlendirildi. Alıcı ve vericilerin demografik özellikleri, greft fonksiyon testleri, COVID-19 PCR sonuçları, HLA uyumları, sıcak-soğuk iskemi süreleri ve nakil sonrası görülen komplikasyonları kaydedildi. İndüksiyon tedavisi olarak hastalar antitimusit globülin (ATG) uygulanan Grup 1 ve Basiliksimab uygulananlar Grup 2 olmak üzere iki gruba ayrlld. Gruplar preoperatif ve postoperatif 1. Gün 7. Gün ve 1. Ay serum kreatinin düzeyleri, ATG kümülatif düzeyi, HLA uyumları açlarından değerlendirildi.

Bulgular Merkezimizde Mart 2020 Kasım 2020 tarihleri arasında 22 böbrek nakli operasyonu gerçekleştirildi. 21 hastaya canlı vericili böbrek nakli uygulandı. Hastaların 7’si kadın 14’ü erkekti. Hastaların ortalama yaşı $41,95 \pm 15,11$ yl ve vücut kitle indeksi $26,37 \pm 5,04 \mathrm{~kg} / \mathrm{m} 2$ idi. İndüksiyon tedavisi olarak hastaların 7 'sine ATG, 13 'üne basiliksimab uygulandı. Tam uyum olan bir hastaya indüksiyon tedavisi uygulanmadı. Erken dönemde akut rejeksiyon veya herhangi bir nedenle greft disfonksiyonu açısından istatistiksel olarak iki grup arasinda anlamlı fark yoktu (p>0.05). Ameliyat sonrası 6 aylık dönem içerisinde 3 hastada COVID-19 enfeksiyonu geliști. Pandemi döneminde bulas sıklğııın azaldığı dönemlerde yakın takip ve sıkı izolasyon tedbirleri altında deneyimli merkezlerde böbrek nakli operasyonları düșük yoğunlukta yapilabilir. Böbrek nakli, kronik böbrek yetmezliği, laparoskopik donör nefrektomi, COVID-19, indüksiyon tedavisi

Objective Due to the COVID-19 pandemic, renal transplantation operations were either stopped or restricted to be performed in selected patient groups in many centers globally. When evaluated together with the kidney transplantation process surgery and immunosuppression therapy applied in the postoperative period, it is a complex procedure, and requires close follow-up. The purpose of our study; to present the renal transplantation operations that performed during the pandemic process, the pre-operative preparation of the patients, the post-operative follow-up processes, and applied treatment approaches.

Method Renal transplantation operations which are performed in our transplant center during the pandemic were evaluated retrospectively. The demographic characteristics of the recipients and donors, graft function tests, COVID-19 PCR results, HLA matches, hot-cold ischemia times and post-transplantation complications were recorded. As induction therapy, the patients were divided into two groups as Group 1 with antithymuside globulin (ATG), and Group 2 with Basiliximab. The groups were evaluated in terms of preoperative and postoperative day 1 , day 7 , and 1st month serum creatinine levels, ATG cumulative level and HLA compatibility.

Results Twenty-two kidney transplantations were performed in our center between March 2020 and November 2020. Living donor kidney transplantation was performed in 21 patients. There were 7 female and 14 were male patients. The mean age of the patients was $41.95 \pm 15.11$ years and the body mass index was $26.37 \pm 5.04 \mathrm{~kg} / \mathrm{m} 2$. As induction therapy, ATG was applied to 7 patients and basiliximab to 13 patients. Induction therapy was not applied to one patient with full compliance. There was no statistically significant difference between the two groups in terms of early acute rejection or graft dysfunction for any reason ( $p>0.05)$. COVID-19 infection developed in 3 patients within a 6-month postoperative period.

Conclusion During the pandemic period when the frequency of transmission is decreasing kidney transplantation operations can be performed at low intensity in experienced centers under close follow-up and strict isolation measures during periods

Keywords Kidney transplantation, chronic renal disease, laparoscopic donor nephrectomy, COVID-19, induction therapy 


\section{INTRODUCTION}

Böbrek nakli (BN), son dönem böbrek hastalı̆̆ı durumunda seçilebilecek en iyi renal replasman tedavi yöntemidir ve başarılı bir BN, hastanın sağ kalımı ve yaşam kalitesini önemli ölçüde arttırmaktadır1. Ancak bu hastalar ömür boyu immunsupresif ilaç kullanmakta ve enfeksiyonlara karşı daha duyarlı hale gelmektedir. İmmunsüpresyon olarak, böbrek alıcılarına nakil sırasında indüksiyon tedavisi (antitimosit globülin (ATG), basiliksimab veya alemtuzumab) ve ardından prednizon, kalsinörin inhibitörü (takrolimus veya siklosporin) veya mTOR inhibitörü (sirolimus veya everolimus) ve antimetabolitten (mikofenolat mofetil, azatioprin) oluşan bir idame immünosupresif tedavi uygulanır². Uzun süreli immünosupresyon, artmış enfeksiyon komplikasyonları riski ile ilişkilidir ve transplant alıcıları özellikle solunumsal RNA virüslerinden kaynaklanan enfeksiyonlara daha duyarlıdir. ${ }^{3}$

Solunumsal RNA virüsü olan koronavirüs, 2019 yllının sonunda Çin'in Wuhan kentinde ciddi akut solunum yetmezliği yapan salgına neden oldu4. Hızla ilerleyen salgın 11 Mart 2020'de Dünya Sağlık Örgütü tarafından pandemi olarak kabul edildi ${ }^{4}$. Hastalığın yaygın semptomları arasında ateş yüksekliği, öksürük, nefes darlığı ve miyalji yer alırken halsizlik, baş ağrısı, koku ve tat duyu kaybı, ishal ve baş dönmesi gibi semptomlarda bildirilmiştir ${ }^{5}$. Enfeksiyon, sıklıkla semptomatik hastalar tarafından öksürme ve hapşırma sırasında üretilen büyük damlacıklar yoluyla bulaşıyordu, ancak semptomsuz kişilerden veya semptomların başlamasından önce de bulaş görülebiliyordu ${ }^{6}$. Hastalığa bağlı ölüm oranlarının ileri yaş, erkek cinsiyeti, kardiyovasküler hastalıklar, diyabet, kronik akciğer hastalıkları, hipertansiyon ve kanser gibi komorbid durumlar varlığında çok daha yükseldiği bildirilmiştir. Benzer şekilde böbrek alıcılarında da genel populasyona göre daha yüksek ölüm oranı olduğu bildirildi ${ }^{8}$. Ülkemizde ilk pandemi vakaları mart ayında görülmeye başlandı. Nisan ayı itibarı ile ülke genelinde sağlık sistemi ile ilgi olarak planlı operasyonlar durduruldu ve bazı hastaneler COVID hastalarına bakmak üzere yeniden dizayn edildi. Hastal1- ğın kontrol altına alınmasıyla birlikte haziran ayı sonunda pandemiye karşı koruyucu önlemler alınarak elektif cerrahi operasyonlar ile birlikte böbrek nakil operasyonları da başladı. Hasta sayılarının artmaya başlamasıyla birlikte kasım ayında nakil operasyonları tekrar durduruldu.

$\mathrm{Bu}$ çalışmanın amacı, pandemi sürecinde yapılan böbrek nakil operasyonlarını, hastaların operasyon öncesi hazırlık, operasyon sonrası takip süreçlerini ve uygulanan tedavi protokollerini sunmaktır.

\section{MATERYAL ve METOD}

Sakarya Üniversitesi Eğitim ve Araştırma Hastanesi Böbrek Nakil Merkezinde COVID-19 pandemisi döneminde Mart 2020- Eylül 2020 tarihleri arasında yapılan böbrek nakli operasyonları retrospektif olarak değerlendirildi. Çalışmanın etik onamı Sakarya Üniversitesi Etik kurulundan alınmıştır (Tarih: 15/12/2020, karar no:641). Merkezimizde, bu süre içerisinde özellikle preemtif hastaların nakil operasyonlarına öncelik verildi ve sıkı izolasyon tedbirleri alınarak biri kadavradan nakil olmak üzere 22 böbrek nakli operasyonu gerçekleştirildi. Tüm hastalar nakil öncesi böbrek nakil konseyinde değerlendirildi. Nakil planlanmadan önce alıcı ve verici şüpheli temas yönünden sorgulandi. Hastalara nakil süreci anlatıldı ve pandemi nedeniyle izolasyon kurallarına uymaları gerektiği söylendi. Hasta onamları, pandemi ile ilgili riskler de belirtilerek alındı. Planlanan nakilden bir hafta önce alıcı, verici ve refakatçiye PCR testi yapıldı. PCR testinin negatif gelmesi üzerine alıc1, verici hastanede, refakatçi ise evinde izolasyona tabi tutuldu. Ameliyattan bir gün önce kontrol PCR testinin negatif olmasıyla birlikte nakil operasyonu gerçekleştirildi. Hastaları tedavi eden hastane personeli de izolasyon kurallarına dikkat ederek tedavileri gerçekleştirdi.

Tüm verici ameliyatları laparoskopik olarak gerçekleștirildi. Böbrek iliak alana retroperitoneal olarak yerleştirildi. Renal arter ile eksternal iliak arter arasında ve renal ven ile eksternal iliak ven arasında uç-yan anastomozlar yapıldı. Üreter anastromozu mesaneye (lich-Gregoir üreteroneo- 
sistostomi) yapıldı.

Böbrek alıcılarına nakil sırasında indüksiyon tedavisi ve ardından prednizon, kalsinörin inhibitörü ve antimetabolitten oluşan bir idame immünosupresif tedavi uygulandı. Hasta bazlı olmakla beraber alıcı ve verici arasında 3 ve daha az HLA uyumsuzluğu olduğunda basiliksimab (aktive T lenfosit yüzeyindeki interlökin 2 reseptör blokörü) 0 . ve 4 . gün $20 \mathrm{mg}$ intravenöz olarak uygulandı. 3 veya daha fazla HLA uyumsuzluğu olduğunda ATG intravenöz olarak uygulandı. Tüm hastalara antibiyotik profilaksisi için operasyondan bir saat önce $1 \mathrm{gr}$ flk sefazolin sodyum intravenöz olarak uygulandı. Böbrek alıcı ve vericilerin tüm demografik özellikleri ve laboratuvar verileri kaydedildi. Hastaların diyaliz süreleri, primer hastalığı ve komorbid hastalık varlığı, akut dönem cerrahi ve klinik komplikasyonları, hastaneye yatış süreleri, greft fonksiyonları, kümülotif ATG dozu, anastomoz yapılan renal arter ve ven sayısı, sıcak iskemi ve soğuk iskemi süreleri kaydedildi.

\section{İstatistiksel değerlendirme}

Çalışmanın istatistiksel analizinde SPSS 26 paket programı kullanılarak sosyo demografik ve klinik verilerin ve tanımlayıcı istatistiklerin sıklığı sayı, dağılım ve yüzdeler olarak hesaplandı. Vaka ve kontrol grubu arasındaki istatistiksel anlamlılığın tespitinde normal dağılım gösteren sürekli değişkenler bağımsız örneklem t testi ile, normal dağılım göstermeyen değişkenler Mann Witney U testiyle ile karşılaştırılmıştır. \%95 ( $\mathrm{p}<0.05)$ anlamlılık düzeyi olarak kabul edilmiştir.

\section{SONUÇLAR}

Merkezimizde biri kadavra nakil olmak üzere 22 hastaya

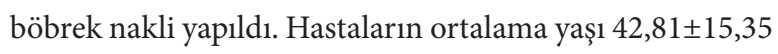
yıl idi. Hastaların \%68,2'sı erkek, \%31,8'ü kadın idi. Böbrek yetmezliğinin primer nedeni ve hastaların diyaliz durumu tablo-1 de verilmiştir. Hastalarımızın hiçbiri daha önce COVID-19 tanısı almamıştı ve nakil sonrası 1 aylık süre içerisinde hiçbir hastamızda COVID-19 enfeksiyonu gelişmedi. Komorbidite olarak 9 (\% 40,9) hastamızda hiper- tansiyon, $5(\% 22,7)$ hastamızda diyabet vardı. 5 (\%22,7) hastaya çift renal arter anastomozu yapıldı.

\begin{tabular}{|c|c|c|}
\hline \multicolumn{3}{|c|}{$\begin{array}{l}\text { Tablo-1: Nakil yapılan hastaların demografik özellikleri, diyaliz } \\
\text { durumu ve primer hastalık oranları }\end{array}$} \\
\hline & Özellik & Sonuç \\
\hline & Yaş $(\mathrm{yl} 1)^{*}$ & $42,81 \pm 15,35$ \\
\hline \multirow[t]{2}{*}{ Cinsiyet } & Erkek $(\mathrm{n}, \%)$ & $15(\% 68,2)$ \\
\hline & $\operatorname{Kadın}(n, \%)$ & $7(\% 31,8)$ \\
\hline \multirow[t]{3}{*}{ Diyaliz durumu } & Preemtif $(n, \%)$ & $16(\% 72,7)$ \\
\hline & Hemodiyaliz $(\mathrm{n}, \%)$ & $6(\% 27,3)$ \\
\hline & Diyaliz süresi (ay)** & $6(6-120)$ \\
\hline \multirow[t]{7}{*}{ Primer Hastalık } & Diyabetes mellitus (n,\%) & $5(\% 22,7)$ \\
\hline & Hipertansiyon (n,\%) & $8(\% 36,4)$ \\
\hline & Glomerulonefrit $(\mathrm{n}, \%)$ & $2(\% 9,1)$ \\
\hline & $\operatorname{Vur}(\mathrm{n}, \%)$ & $2(\% 9,1)$ \\
\hline & $\begin{array}{l}\text { Polikistik Böbrek Hastalığ } 1 \\
\text { (n,\%) }\end{array}$ & $2(\% 9,1)$ \\
\hline & Taş (n,\%) & $1(\% 4,5)$ \\
\hline & İdiyopatik (n,\%) & $2(\% 9,1)$ \\
\hline \multirow[t]{2}{*}{ Nakil şekli } & Kadavra $(\mathrm{n}, \%)$ & $1(\% 4.5)$ \\
\hline & Canlı (n,\%) & $21(\% 95,5)$ \\
\hline $\begin{array}{l}{ }^{*} \text { Ortalama } \pm \text { Stan } \\
{ }^{* *} \text { Median (min., }\end{array}$ & $\begin{array}{l}\text { t sapma } \\
\text { x.) }\end{array}$ & \\
\hline
\end{tabular}

$21(\% 95,5)$ hastamıza canlı vericili böbrek nakli yapıldı. Verici ameliyatları laparoskopik olarak yapıldı. Hastaların demografik verileri, sıcak iskemi ve soğuk iskemi süreleri, diyaliz alan ve preemtif hasta sayıları tablo-2 de verilmiştir.

Bir hastamızda tam uyum olduğu için indüksiyon tedavisi uygulanmadi. İndüksiyon tedavisi olarak hastaların immünolojik risklerine göre basiliksimab veya ATG uygulandı. Canlı donör nakil yapılan 20 hastanın HLA uyumu, kümülatif ATG dozu, nakil öncesi ve sonrası serum kreatinin değerleri tablo-3 de verilmiştir.

Bir hastamızda tacrolimusa bağlı rabdomiyoliz gelişmesi üzerine idame tedavi olarak mTOR inhibitörüne geçildi. Bu hasta 38 yaşında erkek hasta idi ve postoperatif üçüncü ayda COVID-19 enfeksiyonuna yakalandı. Böbrek alıcısı olan 41 yaşında ve 56 yaşında iki hastamızda ve böbrek 
J Biotechnol and Strategic Health Res. 2021;5(1):78-84

FIRAT, AKIN, DHEIR, ÇELEBİ, SARIGEDİK, YİĞİT, ALTINTOPRAK, COVID-19 Pandemisi Sırasında Canlı Donör Böbrek Nakli

\begin{tabular}{|c|c|c|c|c|c|}
\hline & & $\operatorname{Kad} ı(\operatorname{mean} \pm S D)$ & $\operatorname{Erkek}($ mean $\pm \mathrm{SD})$ & Toplam & $\mathrm{P}$ \\
\hline \multirow{4}{*}{$\begin{array}{l}\text { Böbrek } \\
\text { Verici }\end{array}$} & Sayi (n) & 8 & 13 & 21 & \\
\hline & Yaş $(\mathrm{yll})^{*}$ & $44,0 \pm 13,12$ & $44,85 \pm 12,75$ & $44,52 \pm 12,57$ & 0,885 \\
\hline & VKİ $(\mathrm{kg} / \mathrm{m} 2)^{*}$ & $28,37 \pm 5,94$ & $27,8 \pm 3,7$ & $28,01 \pm 4,54$ & 0,784 \\
\hline & Nakil sonrası ilk 6 ayda covid-19 yakalanan hasta sayısı & 0 & 1 & 1 & \\
\hline \multirow{7}{*}{$\begin{array}{l}\text { Böbrek } \\
\text { alıcı }\end{array}$} & Sayı & 7 & 14 & 21 & \\
\hline & Yaş $(\mathrm{yll})^{*}$ & $45,71 \pm 14,27$ & $40,07 \pm 15,78$ & $41,95 \pm 15,11$ & 0,436 \\
\hline & Vki $(\mathrm{kg} / \mathrm{m} 2)^{*}$ & $27,43 \pm 6,47$ & $25,85 \pm 4,35$ & $26,37 \pm 5,04$ & 0,513 \\
\hline & Preemtif/diyaliz (n) & $5 / 2$ & $11 / 3$ & $16 / 5$ & 0,717 \\
\hline & Sıcak iskemi süresi (saniye)* & $179,14 \pm 54,87$ & $153,0 \pm 40,26$ & $161,71 \pm 46,0$ & 0,228 \\
\hline & Soğuk iskemi süresi (dakika)* & $71,71 \pm 13,35$ & $75,71 \pm 13,80$ & $74,38 \pm 13,46$ & 0,535 \\
\hline & Nakil sonrası ilk 6 ayda covid-19 yakalanan hasta sayısı & 0 & 3 & 3 & \\
\hline
\end{tabular}

Tablo-3: Canlı donör nakillerde indüksiyon tedavisinin karşılaştırılması

\begin{tabular}{|c|c|c|c|}
\hline & ATG & Basiliksimab & $\mathrm{p}$ \\
\hline CİNSİYET(E/K) (n) & $6 / 1$ & $7 / 6$ & 0,136 \\
\hline ATG Kümülatif Doz $(\mathrm{mg})^{*}$ & $400(400-700)$ & - & \\
\hline HLA-uyumu * (missmatch) & $3(3-6)$ & $3(0-5)$ & 0,028 \\
\hline HLA-uyumu* (Haplotip) & $1(0-1)$ & $1(0-2)$ & 0,049 \\
\hline Nakil öncesi serum kreatinin $(\mathrm{mg} / \mathrm{dl})^{\star *}$ & $7,24 \pm 1,69$ & $6,23 \pm 1,77$ & 0,258 \\
\hline Nakil sonrası 7. gün serum kreatinin $(\mathrm{mg} / \mathrm{dl}){ }^{* *}$ & $1,30 \pm 0.72$ & $1,25 \pm 0.38$ & 0,833 \\
\hline Nakil sonrası 1 . Ay serum kreatinin $(\mathrm{mg} / \mathrm{dl}){ }^{* *}$ & $1,33 \pm 0.40$ & $1,20 \pm 0,31$ & 0,428 \\
\hline Nakil sonrası 3. ay serum kreatinin $(\mathrm{mg} / \mathrm{dl}){ }^{* *}$ & $1,26 \pm 0,31$ & $1,25 \pm 0,29$ & 0,870 \\
\hline Nakil sonrası ilk 6 ayda covid-19 yakalanan hasta sayısı & 2 & 1 & \\
\hline \multicolumn{4}{|c|}{ ATG (antitimosit globulin) $\quad{ }^{*}$ Median $(\min -\max ) \quad{ }^{* *}$ Ortalama \pm Standart sapma Mann Witney U } \\
\hline
\end{tabular}

vericisi olan 67 yaşında bir hastamızda COVİD-19 enfeksiyonu gelişti. COVİD-19 enfeksiyonu gelişen böbrek alıcılarında uygulanan immunsüpresif tedavide ilaçların doz azaltılmasına gidildi. Hiçbir hastamızda immunsüpresif ilaçlarda uygulanan doz azaltımına bağlı klinik olarak gözlemlenen akut rejeksiyon oluşmadı.

Nakil ekibimizden bir nefrolog, iki cerrah, 3 ameliyathane hemşiresi ve 2 anestezist pandeminin ikinci pik yaptığ kasım ayından sonra korona virüs hastalığına yakalandı ve 14 günlük istirahatten sonra çalışmaya başladılar.

\section{TARTIŞMA}

Çalışmamız, pandemi sırasında uygun hasta populasyo- nunda canlıdan böbrek nakli operasyonlarının özel önlemler eşliğinde güvenle yapılabileceğini gösterdi. Hastaların hiçbirinde operasyon öncesi ve operasyon sonrası ilk otuz günlük süre içerisinde COVID-19 ile ilgili sorun yaşanmadı. Nakil güvenliğini sağlamak için COVID-19 yayılma alanlarında verici ve alıcı taraması gereklidir. Mart 2020'nin sonlarında, ABD’deki birçok nakil merkezi canlı donör böbrek naklini tamamen askıya aldığını ve kadavra böbrek nakli için kısıtlamalar uyguladığını bildirdi ${ }^{9}$ Benzer şekilde Pandemi sırasında böbrek nakli alıcıları için artan risk nedeniyle istisnai durumlar dışında nakil programlarının ertelenmesi tavsiye edilmiştir ${ }^{10}$. Biz de merkezimizdeki nakil ameliyatlarını, COVID-19 enfekte hasta sayısında belirgin azalmanın olduğu Haziran 2020 sonuna 
kadar durdurma kararı aldık. Nakil operasyonları başladığında hastalar titizlikle değerlendirildi ve hastalara yapılan PCR testi yanlış negatiflik ihtimali nedeniyle operasyondan bir gün önce tekrar edildi ${ }^{11}$. Torax BT semptomatik hastalara önerildiği için çektirilmedi ${ }^{12}$.

Pandemi nedeniyle kadaverik ve canlı nakil programı aksayınca üremik hastalar diyaliz programına devam etmek zorunda kalmaktadır. COVID-19 salgını, etkili antiviral ilaçlar ve aşılar geliştirilinceye kadar küresel halk sağlığı ve transplantasyon programlarını tehdit etmeye devam edecektir. Bu durum üremik hastalarda morbidite ve mortalite oranların artmasına neden olacaktır.

Solid organ nakil merkezlerindeki nakil aktivitesi azaltma gerekçeleri risk toleransına, yerel COVID-19 aktivitesinin derecesine ve tıbbi kaynak kapasitesine dayanmalıdır ${ }^{13}$. Genel olarak, DSÖ tarafından tanımlanan algoritmalarına göre, önlem alınarak nakil işlemleri yapılabilir. Bununla birlikte, toplumda bulaşmanın (çok sayıda izlenemeyen vaka) arttığg bölgelerde, hastalar ve sağlık hizmetleri arasında artan enfeksiyon riski olması ve asemptomatik bireyleri belirlenememesi nedeniyle nakil için geçici kademeli bir askıya alma önerilmektedir ${ }^{14}$.

Koronavirüs enfeksiyonunun neden olduğu aşırı sitokin salınımı, ARDS veya ekstrapulmoner çoklu organ yetmezliğine yol açarak enfeksiyonun alevlenmesinden sorumludur ve bu mortalitede önemli bir faktör olarak görülür ${ }^{15}$. Ayrıca COVID-19 hastalarının yüksek bir lenfopeni prevalansına sahip olduğu gösterilmiştir ${ }^{16}$. Nakilli hastalarda verilen immünsüpresif tedavinin, aşırı stokin salınımının etkilerini azaltabileceği böylece morbidite ve mortalitenin düşebileceği ileri sürülmüştür ${ }^{17,18}$. Ancak böbrek alıcılarında mortalite oranlarının normal popülasyona göre çok daha yüksek olduğu görülmüş ve bunun temel sebebi olarak immunsüpresyona bağlı lenfopeni sorumlu tutulduğu gibi $^{19}$ bu hastalarda sıklıkla birlikte görülen diyabet, hipertansiyon ve kardiyovasküler hastalıklar gibi komorbiditeler de sorumlu tutulmuştur ${ }^{20,21}$. Hastalarımızın hiçbirinde immünsüpresiyona bağlı lenfopeni gelişmedi fakat bazı hastalarımızda tansiyon ve şeker hastalığı gibi ek hastalıklar vardi.

Böbrek alıcıların indüksiyon tedavisinde ATG ve basiliksimab yaygın olarak kullanılmaktadır ${ }^{22}$. Basiliksimab, IL-2'nin aracılık ettiği $\mathrm{T}$ hücre proliferasyonunu ve aktivasyonunu etkili bir şekilde inhibe edebilen interlökin-2 reseptörü (IL2R) için monoklonal bir antikordur. ATG, T hücrelerinde çok sayıda yüzey antijenini hedefleyerek $\mathrm{T}$ hücrelerinin daha etkili tüketilmesine ve NK hücreleri ve B hücreleri üzerinde ek etkilere izin verir ${ }^{23}$. Böbrek nakli hastalarında akut rejeksiyon gelişmesi açısından düşük doz ATG ile indüksiyonun, basiliksimabdan daha iyi bir seçenek olabileceği belirtilmişş ${ }^{24}$ ancak farklı bir çalışmada iki grup arasında akut rejeksiyon atakların önleme açısından bir farklılık olmadı̆̆ pandemi süresince düşük immunolojik riskli hastalarda indüksiyon tedavisi olarak basiliksimab kullanılmıştır. Pandemi öncesinde bu hastalara düşük doz ATG tedavisi uygulamaktaydık. Kısa süreli sonuçlarımızda her iki grup arasında anlamlı fark yoktur.

Hem COVID-19 hakkında farkındalığ 1 yaymak için çevrimiçi eğitim hem de çevrimiçi takip, solid organ transplant hastalarında enfeksiyon riskini en aza indirebilir. Çalışmamızda, genel popülasyonla karşılaştırıldığında, böbrek nakilli hastalarda COVID-19 enfeksiyon riski daha yüksek bulunmadı. Bu hastalarda kullanılan farklı immünsüpresif yaklaşımlar fırsatçı enfeksiyon ve akut rejeksiyon atakları bakımından herhangi bir risk oluşturmamış.

Çalışmanın kısıtlayıcı yanı kısa süreli ve küçük çaplı olmasıdır. Ayrıca çalışmamız sadece düşük immünolojik riske sahip hasta grubu içeriyordu.

\section{SONUÇ}

Nakil olan hastalar, pandemi döneminde temizlik ve izolasyon kurallarına daha fazla dikkat ediyor olabilmesine rağmen enfeksiyonun yayılma hızı ve mortalitesi göz önüne alındığında, iyi sonuçlarına rağmen nakil operasyonla- 
rının belli zamanlarda durdurulması gerekli olabilir. Genel olarak, canlıdan böbrek nakli COVID-19'un olumsuz etkisinden korumak için çok daha fazla çalışmaya ve spesifik klinik kılavuzlara ihtiyaç vardır.

\section{Etik Komite Onayı}

Çalışmamız Sakarya Üniversitesi Tıp Fakültesi Girişimsel Olmayan Klinik Araştırmalar Etik Kurulu (Tarih: 15/12/2020, karar no:641) tarafindan onaylandi.

\section{Çıkar Çatışması}

Yazarlar, bu makalenin araştırılması, yazarlığı ve / veya yayınlanması ile ilgili olarak potansiyel çıkar çatışması bildirmemişlerdir.

\section{Yazar Katkıları}

Fikir - N.F., H.D.; Denetleme - F.Ç., F.A; Malzemeler N.F.,H.D.,E.A, F.A.; Veri toplanması ve işlemesi - N.F., M.Y.; Analiz ve yorum - N.F.,E.S.; Yazıyı yazan - N.F.,E.A.

\section{Hakem değerlendirmesi}

Diş bağımsız.

\section{Teşekkür}

Doç.Dr.Fikret Halis ve organ nakli nakli koordinatörü Gülercan Şenel'e, daha önce yayınlanmamış çalışmayla ilgili ek verileri sağladıkları için teşekkür ediyoruz.

\section{Ethics Committee Approval}

Our study was approved by the Sakarya University Non-Interventional Clinical Research Ethics Committee (Date: 15/12/2020, decision no: 641).

\section{Conflict of Interest}

The author(s) declared no potential conflicts of interest with respect to the research, authorship, and/or publication of this article.

\section{Author Contributions}

Concept - N.F., H.D.; Supervision - F.Ç.,F.A.; Materials - - N.F.,H.D.,E.A,F.A.; Data Collection and Processing N.F., M.Y.; Analysis and Interpretation - N.F.,E.S.; Writing - N.F.,E.A.

\section{Peer-review}

Externally peer-reviewed.

\section{Acknowledge}

We thank Doç.Dr.Fikret Halis and transplant organ transplant coordinator Gülercan Şenel for providing us the additional data relating to his trial that were not previously published 
J Biotechnol and Strategic Health Res. 2021;5(1):78-84

FIRAT, AKIN, DHEIR, ÇELEBİ, SARIGEDİK, YİĞİT, ALTINTOPRAK, COVID-19 Pandemisi Sırasında Canlı Donör Böbrek Nakli

\section{References}

1. Firat N, Dheir H, Akin E, et al. Canlı Donörden Böbrek Nakli: Illk Deneyimlerimiz. Online Türk Sağllk Bilimleri Dergisi. 2020;5(2):356-363. doi:10.26453/otjhs.705092

2. Scherer MN, Banas B, Mantouvalou K, et al. Current concepts and perspectives of immunosuppression in organ transplantation. Langenbecks Arch Surg. 2007;392(5):511-523. doi:10.1007/s00423-007-0188-z

3. Manuel O, Estabrook M. RNA respiratory viral infections in solid organ transplant recipients: Guidelines from the American Society of Transplantation Infectious Diseases Community of Practice. Clin Transplant. 2019;33(9). doi:10.1111/ctr.13511

4. Del Rio C, Malani PN. 2019 Novel Coronavirus-Important Information for Clinicians. JAMA. 2020;323(11):1039-1040. doi:10.1001/jama.2020.1490

5. Chen Q, Zheng Z, Zhang C, et al. Clinical characteristics of 145 patients with corona virus disease 2019 (COVID-19) in Taizhou, Zhejiang, China. Infection. Published online April 28, 2020:1-9. doi:10.1007/s15010-020-01432-5

6. Rothe C, Schunk M, Sothmann P, et al. Transmission of 2019-nCoV Infection from an Asymptomatic Contact in Germany. N Engl J Med. 2020;382(10):970-971. doi:10.1056/ NEJMc2001468

7. Alberici F, Delbarba E, Manenti C, et al. A single center observational study of the clinical characteristics and short-term outcome of 20 kidney transplant patients admitted for SARS-CoV2 pneumonia. Kidney Int. 2020;97(6):1083-1088. doi:10.1016/j. kint.2020.04.002

8. Kataria A, Yakubu I, Winstead R, Gowda M, Gupta G. COVID-19 in Kidney Transplantation: Epidemiology, Management Considerations, and the Impact on Kidney Transplant Practice. Transplant Direct. 2020;6(8). doi:10.1097/TXD.0000000000001031

9. Boyarsky BJ, Po-Yu Chiang T, Werbel WA, et al. Early impact of COVID-19 on transplant center practices and policies in the United States. Am J Transplant. 2020;20(7):1809-1818. doi:10.1111/ajt.15915

10. Coates PT, Wong G, Drueke T, Rovin B, Ronco P. Early experience with COVID-19 in kidney transplantation. Kidney Int. 2020;97(6):1074-1075. doi:10.1016/j.kint.2020.04.001

11. West CP, Montori VM, Sampathkumar P. COVID-19 Testing. Mayo Clin Proc. 2020;95(6):1127-1129. doi:10.1016/j.mayocp.2020.04.004

12. Ai T, Yang Z, Hou H, et al. Correlation of Chest CT and RT-PCR Testing in Coronavirus Disease 2019 (COVID-19) in China: A Report of 1014 Cases. Radiology. Published online February 26, 2020. doi:10.1148/radiol.2020200642
13. Kumar D, Manuel O, Natori Y, et al. COVID-19: A global transplant perspective on successfully navigating a pandemic. Am J Transplant. 2020;20(7):1773-1779. doi:10.1111/ ajt.15876

14. Coronavirus Disease (COVID-19) Situation Reports. Accessed March 8, 2021. https:// www.who.int/emergencies/diseases/novel-coronavirus-2019/situation-reports

15. Ye Q, Wang B, Mao J. The pathogenesis and treatment of the 'Cytokine Storm' in COVID-19. J Infect. 2020;80(6):607-613. doi:10.1016/j.jinf.2020.03.037

16. Guan W, Ni Z, Hu Y, et al. Clinical Characteristics of Coronavirus Disease 2019 in China. N Engl J Med. Published online February 28, 2020. doi:10.1056/NEJMoa2002032

17. Joob B, Wiwanitkit V. COVID-19 and Organ Transplantation. Int J Organ Transplant Med. 2020;11(2):93.

18. Akalin E, Azzi Y, Bartash R, et al. Covid-19 and Kidney Transplantation. N Engl J Med. 2020;382(25):2475-2477. doi:10.1056/NEJMc2011117

19. Banerjee D, Popoola J, Shah S, Ster IC, Quan V, Phanish M. COVID-19 infection in kidney transplant recipients. Kidney Int. 2020;97(6):1076-1082. doi:10.1016/j.kint.2020.03.018

20. Goyal P, Choi JJ, Pinheiro LC, et al. Clinical Characteristics of Covid-19 in New York City. N Engl J Med. 2020;382(24):2372-2374. doi:10.1056/NEJMc2010419

21. Imam A, Abukhalaf SA, Imam R, Abu-Gazala S, Merhav H, Khalaileh A. Kidney Transplantation in the Times of COVID-19 - A Literature Review. Ann Transplant. 2020;25:e925755. doi:10.12659/AOT.925755

22. Bouvy AP, Klepper M, Kho MML, et al. The impact of induction therapy on the homeostasis and function of regulatory T cells in kidney transplant patients. Nephrol Dial Transplant. 2014;29(8):1587-1597. doi:10.1093/ndt/gfu079

23. Huang H-F, Zhou J-Y, Xie W-Q, Wu J-Y, Deng H, Chen J-H. Basiliximab versus rabbit antithymocyte globulin as induction therapy for living-related renal transplantation: a single-center experience. Int Urol Nephrol. 2016;48(8):1363-1370. doi:10.1007/s11255016-1307-y

24. Patel HV, Kute VB, Vanikar AV, et al. Low-dose rabbit anti-thymoglobin globulin versus basiliximab for induction therapy in kidney transplantation. Saudi J Kidney Dis Transpl. 2014;25(4):819-822. doi:10.4103/1319-2442.135057

25. Wang K, Xu X, Fan M. Induction therapy of basiliximab versus antithymocyte globulin in renal allograft: a systematic review and meta-analysis. Clin Exp Nephrol. 2018;22(3):684693. doi:10.1007/s10157-017-1480-z 